REVIEW

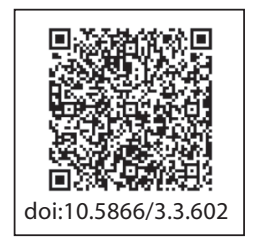

\title{
Surface characteristics of Titanium Dental Implants for Rapid Osseointegration
}

\author{
Surender L R ${ }^{1}$, Rekha Rani $K^{2}$, Veerendra Nath Reddy $\mathrm{P}^{3}$, Indumathy $\mathrm{P}^{4}$
}

Professor \& HOD ${ }^{1}$

Department of Conservative \& Endodontics. MNR Dental College, Sanga Reddy,

\author{
Professor \& HOD ${ }^{2}$ \\ Reader $^{3}$ \\ Sr. Lecturer ${ }^{4}$ \\ Dept. of Periodontics \\ Panineeya Dental Sciences, Hyderabad, \\ Andhra Pradesh, India
}

\section{Article Info}

Received: April 15, 2011

Review Completed: May, 17, 2011

Accepted: June, 19, 2011

Available Online: October, 2011

(c) NAD, 2011 - All rights reserved

\begin{abstract}
:
The osseointegration rate of titanium dental implants is related to their composition and surface roughness. Rough-surfaced implants favor both bone anchoring and biomechanical stability. Osteoconductive calcium phosphate coatings promote bone healing and apposition, leading to the rapid biological fixation of implants. The different methods used for increasing surface roughness or applying osteoconductive coatings to titanium dental implants are reviewed. Surface treatments, such as titanium plasma-spraying, grit-blasting, acid-etching, anodization or calcium phosphate coatings, and their corresponding surface morphologies and properties are described. Most of these surfaces are commercially available and have proven clinical efficacy ( $>95 \%$ over 5 years). The precise role of surface chemistry and topography on the early events in dental implant osseointegration remain poorly understood. In addition, comparative clinical studies with different implant surfaces are rarely performed. The future of dental implantology should aim to develop surfaces with controlled and standardized topography or chemistry. This approach will be the only way to understand the interactions between proteins, cells and tissues, and implant surfaces. The local release of bone stimulating or resorptive drugs in the peri-implant region may also respond to difficult clinical situations with poor bone quality and quantity. These therapeutic strategies should ultimately enhance the osseointegration process of dental implants for their immediate loading and longterm success.
\end{abstract}

Key words: Osseointegration, Dental implant Surface roughness, Nano-sized topography Biomimetic calcium phosphate coating

\section{Introduction}

The clinical success of oral implants is related to their early osseointegration. Geometry and surface topography are crucial for the short- and long-term success of dental implants. These parameters are associated with delicate surgical techniques, a prerequisite for a successful early clinical outcome. After implantation, titanium implants interact with biological fluids and tissues. Direct bone apposition

Email for correspondence:

Isurender@yahoo.com onto the surface of the titanium is critical for the rapid loading of dental implants. After the initial stages of osseointegration, both prosthetic biomechanical factors and patient hygiene are crucial for the long-term success of the implants. There are two types of response after implantation.

The first type involves the formation of a fibrous soft tissue capsule around the implant. This fibrous tissue capsule does not ensure proper biomechanical fixation and leads to clinical failure of the dental implant. The second type of bone response is related to direct bone-implant contact without an intervening 
connective tissue layer. This is what is known as osseointegration. This biological fixation is considered to be a prerequisite for implant-supported prostheses and their long-term success. The rate and quality of osseointegration in titanium implants are related to their surface properties. Surface composition, hydrophilicity and roughness are parameters that may play a role in implant-tissue interaction and osseointegration. This review focuses on the different surfaces and methods that aim to accelerate the osseointegration of dental implants. The physical and chemical properties of implant surfaces are discussed in relation to their biological and clinical behavior.

\section{Chemical composition of the surface of dental implants:}

The chemical composition or charges on the surface of titanium implants differ, depending on their bulk composition and surface treatments. The composition and charges are critical for protein adsorption and cell attachment. Dental implants are usually made from commercially pure titanium or titanium alloys. Commercially pure titanium (cpTi) has various degrees of purity (graded from 1 to 4). This purity is characterized by oxygen, carbon and iron content. Most dental implants are made from grade 4 cpTi as it is stronger than other grades. Titanium alloys aremainly composed of Ti6Al4V (grade 5 titanium alloy) with greater yield strength and fatigue properties than pure titanium ${ }^{2}$. The surface chemical composition of titanium implants also affects the hydrophilicity of the surface. Highly hydrophilic surfaces seem more desirable than hydrophobic ones in view of their interactions with biological fluids, cells and tissues. ${ }^{3,4}$ Contact angle measurements give values ranging from $0 \%$ (hydrophilic) to $140 \%$ (hydrophobic) for titanium implant surfaces. ${ }^{3,5,6}$ In a recent animal study, Buser et al. ${ }^{3}$ ] found that a hydrophilic SLA surface gave higher bone-to-implant contact than regular SLA. Nevertheless, previous in vivo studies performed by Albrektsson andco-workers ${ }^{7,8}$ failed to demonstrate higher osseointegrationusing hydrophilic surfaced dental implants.

\section{Surface roughness of dental implants}

There are numerous reports that demonstrate that the surface roughness of titanium implants affects the rate of osseointegration and biomechanical fixation..$^{9,10}$ Surface roughness can be divided into three levels depending on the scale of the features: macro-, micro- and nano-sized topologies. The macro level is defined for topographical features as being in the range of millimetres to tens of microns. This scale is directly related to implant geometry, with threaded screw and macroporous surface treatments giving surface roughness of more than 10_m. Numerous reports have shown that both the early fixation and long-term mechanical stability of the prosthesis can be improved by a high roughness profile compared to smooth surfaces. ${ }^{11,13}$ The high roughness resulted in mechanical interlocking between the implant surface and bone ongrowth. However, a major risk with high surface roughness may be an increase in peri-implantitis as well as an increase in ionic leakage. ${ }^{14} \mathrm{~A}$ moderate roughness of 1-2_m may limit these two parameters. ${ }^{15}$ The microtopographic profile of dental implants is defined for surface roughness as being in the range of 1-10_m. This range of roughness maximizes the interlocking between mineralized bone and the surface of the implant. ${ }^{10,13}$ A theoretical approach suggested that the ideal surface should be covered with hemispherical pits.

Type of implant Surface roughness (_m) Contact angle (\%) References.

$$
\begin{aligned}
& \text { cpTi Ra }=0.22 \pm 0.01 \text { a } 55.4 \pm 4.1^{5,107} \\
& \text { Ti6AI4V Ra }=0.23 \pm 0.01 \mathrm{a} 56.3 \pm 2.7^{5,107} \\
& \text { TPS Ra }=7.01 \pm 2.09 \text { n.d. }{ }^{5} \\
& \text { SLA Sa }=1.15 \pm 0.05138 .3 \pm 4.2^{3} \\
& \text { Modified SLA Sa }=1.16 \pm 0.040^{3} \\
& \text { Plasma-sprayed HA coating } \mathrm{Ra}=1.06 \pm 0.21
\end{aligned}
$$
$57.4 \pm 3.2^{6,108}$

Biomimetic CaP coating $\mathrm{Ra}=1.83 \pm 0.6413 .4 \pm 0.17$

This work a Machined and polished surfaces. boneto-implant contact would be beneficial for allowing high levels of loading. In the cases of insufficient bone quantity or anatomical limitations, short designed implants with a rough surface have demonstrated superior clinical outcomes than smooth surfaces. ${ }^{17,18}$ Numerous studies have shown that surface roughness in this range resulted in greater bone-toimplant contact and higher resistance to torque removal than other types of surface topography. ${ }^{10,13}$ These reports have demonstrated that titanium implants with roughened surfaces have greater contact with bone than titanium implants with smoother surfaces. ${ }^{9,10}$ However, the Cochrane collaboration has not found any clinical evidence demonstrating the superiority of any 
particular implant surface. ${ }^{19}$ Surface profiles in the nanometer range play an important role in the adsorption of proteins, adhesion of osteoblastic cells and thus the rate of osseointegration. ${ }^{20}$ However, reproducible surface roughness in the nanometer range is difficultto produce with chemical treatments. In addition, the optimal surface nano topography for selective adsorption of proteins leading to the adhesion of osteoblastic cells and rapid bone apposition is unknown.Various methods have been developed in order to createa rough surface and improve the osseointegration of titanium dental implants. These methods use titanium plasma-spraying, blasting with ceramic particles, acid-etching and anodization.

\subsection{Roughening of implants by titaniumplasma- spraying:}

A titanium plasma-spraying (TPS) method has been used for producing rough implant surfaces. This method consists in injecting titanium powders into a plasma torch at high temperature. The titanium particles are projected on tothe surface of the implants where they condense and fuse together, forming a film about 30_m thick. The thickness must reach 40-50_m to be uniform. The resulting TPS coating has an average roughness of around 7_m, which increases the surface area of the implant. It has been shown that this threedimensional topography increased the tensile strength at the bone/implant interface. ${ }^{11}$ In this pre-clinical study using minipigs, the bone/implant interface formed faster with a TPS surface than with smooth surface implants presenting an average roughness of $0.2 \_\mathrm{m}$. However, particles of titanium have sometimes been found in the bone adjacent to these implants. ${ }^{21}$ The presence of metallic wear particles from endosseous implants in the liver, spleen, small aggregates of macrophages and even in the para-aortic lymph nodes have also been reported. ${ }^{21}$ Metal ions released fromimplantsmay be the product of dissolution, fretting and wear, and may be a source of concern due to their potentially harmful local and systemic carcinogenic effects. ${ }^{22,23}$ However, the local and systemic adverse effects of the release of titanium ions have not been universally recognized. In a clinical study comparing SLA and TPS implant surfaces, no clinical difference was observed between these two surfaces. ${ }^{24}$ In a pre-clinical model, the percentage of bone/implant contact was found to be inferior for the TPS surface than for plasmasprayed hydroxyapatite-coated implant. ${ }^{25}$ Nowadays, there is a consensus on the clinical advantages of implanting moderately rough surfaced implants (in the micrometric range) rather than using rough plasmasprayed implant surfaces. ${ }^{11,26}$

\subsection{Roughening of implants by grit-blasting}

Another approach for roughening the titanium surface consists in blasting the implants with hard ceramic particles. ceramic particles are projected through a nozzle at high velocity by means of compressed air. Depending on the size of the ceramic particles, different surface roughnesses can be produced on titanium implants. The blasting material should be chemically stable, biocompatible and should not hamper the osseointegration of the titanium implants. Various ceramic theparticles have been used, such as alumina, titanium oxide and calcium phosphate particles. Alumina (Al2O3) is frequently used as a blasting material and produces surface roughness varying with the granulometry of the blasting media. However, the blasting material is often embedded into the implant surface and residue remains even after ultrasonic cleaning, acid passivation and sterilization. Alumina is insoluble in acid and is thus hard to remove from the titanium surface. In some cases, these particles have been released into the surrounding tissues and have interfered with the osseointegration of the implants. Moreover, this chemical heterogeneity of the implant surface may decrease the excellent corrosion resistance of titanium in a physiological environment ${ }^{27}$. Titanium oxide is also used for blasting titanium dental implants. Titanium oxide particles with an average size of 25_m produce a moderately rough surface in the 12_m range on dental implants. An example of a titanium oxideblasted surface is shownin Fig. 2. An experimental study using microimplants in humans has shown a significant improvement for bone-to-implant contact (BIC) for the TiO2 blasted implants in comparison with machined surfaces ${ }^{28}$. Other experimental studies confirmed the increase in BIC for titanium grit-blasted surfaces ${ }^{12,29}$. Other studies have reported high clinical success rates for titanium grit-blasted implants, up to 10 years after implantation ${ }^{30,31}$. Comparative clinical studies gave higher marginal bone levels and survival rates for $\mathrm{TiO} 2$ grit-blasted implants than for machined turned implants ${ }^{32,33}$. Wennerberg et al. ${ }^{13}$ demonstrated with a rabbit model that grit-blasting with $\mathrm{TiO} 2$ or $\mathrm{Al} 2 \mathrm{O} 3$ particles gave similar values of bone-implant contact, but drastically increased the biomechanical fixation of the implants when compared to smooth titanium. These studies have shown that the torque force increased with 
the surface roughness of the implants while comparable values in bone apposition were observed ${ }^{34}$. These studies corroborate that roughening titanium dental implants increases their mechanical fixation to bone but not their biological fixation. A third possibility for roughening titanium dental implants consists in using a biocompatible, osteoconductive and resorbable blasting material. Calcium phosphates such as hydroxyapatite, beta-tricalcium phosphate and mixtures have been considered useful blasting materials. These materials are resorbable, leading to a clean, textured, pure titanium surface. Experimental studies have demonstrated a higher bone-to-implant contact with these surfaces when compared to machined surfaces. ${ }^{35,36}$ Experimental studies have demonstrated a bone-to-implant contact similar to that observed with other blasting surfaces when osseointegration is achieved. ${ }^{37}$

\subsection{Roughening of implants by acid-etching}

Etching with strong acids such as $\mathrm{HCl}, \mathrm{H} 2 \mathrm{SO} 4$, $\mathrm{HNO} 3$ and HF is another method for roughening titanium dental implants. Acid-etching produces micro pits on titanium surfaces with sizes ranging from 0.5 to 2_m in diameter. ${ }^{38,39}$ Acid- etching has been shown to greatly enhance osseointegration. ${ }^{40}$ Immersion of titanium implants for several minutes in a mixture of concentrated $\mathrm{HCl}$ and $\mathrm{H} 2 \mathrm{SO} 4$ heated above $100 \% \mathrm{C}$ (dual acid-etching) is employed to produce a microrough surface. This type of surface promotes rapid osseointegration while maintaining long-term success over 3 years. ${ }^{41}$ It has been found that dual acidetched surfaces enhance the osteoconductive process through the attachment of fibrin and osteogenic cells, resulting in bone formation directly on the surface of the implant. ${ }^{42}$ In the peri-implant area, woven bone with thin trabeculae projecting into the implants, has been described. ${ }^{43}$ These studies hypothesized that implants treated by dual acid-etching have a specific topography able to attach to the fibrin scaffold, to promote the adhesion of osteogenic cells, and thus to promote bone apposition ${ }^{44,45}$ Several experimental studies have reported higher bone-to-implant contact and less bone resorption with dual acid-etched surfaces compared to machined or TPS surfaces..$^{9,46,47}$ Recently, acid-etching methods have been improved in order to increase cell adhesion and bone neoformation. High temperature acid-etching produces a homogeneous microporous surface with higher bone-to-implant contact than TPS surfaces in experimental studies. ${ }^{48,49}$ The wettability of the surface has also been proposed to promote fibrin adhesion. This fibrin adhesion provides contact guidance for the osteoblasts migrating along the surface. An experimental study has demonstrated that a hydrophilic surface greatly improved the bone/ implant contact compared to standard sand-blasted and acid-etched implants in minipigs. ${ }^{3}$ Another approach involves treating titanium dental implants in fluoride solutions. Titanium is very reactive to fluoride ions, forming soluble TiF4. This chemical treatment of the titanium created both a surface roughness and fluoride incorporation favorable to the osseointegration of dental implants. ${ }^{50,51}$ It has been shown that this chemical surface treatment enhanced osteoblastic differentiation in comparison with control samples. ${ }^{52}$ Fluoridated rough implants also withstood greater push-out forces and showed a significantly higher torque removal than the control implants. ${ }^{50,51}$ This chemical treatment may have the potential to further improve implant anchorage in bone by rendering the implant surface bioactive. Nevertheless, chemical treatments might reduce the mechanical properties of titanium. For instance, acid-etching can lead to hydrogen embrittlement of the titanium, creating micro cracks on its surface that could reduce the fatigue resistance of the implants. ${ }^{53}$ Indeed, experimental studies have reported the absorption of hydrogen by titanium in a biological environment. This hydrogen embrittlement of titanium is also associated with the formation of a brittle hybrid phase, leading to a reduction in the ductility of the titanium. This phenomenon is related to the occurrence of fracture mechanisms in dental implants. ${ }^{53}$

\subsection{Roughening of implants by anodization}

Micro- or nano-porous surfaces may also be produced bypotentiostatic or galvanostatic anodization of titanium in strong acids (H2SO4, H3PO4, HNO3, HF) at high current density $(200 \mathrm{~A} / \mathrm{m} 2)$ or potential $(100 \mathrm{~V})$. The result of the anodization is to thicken the oxide layer to more than 1000nm on titanium. When strong acids are used in an electrolyte solution, the oxide layer will be dissolved along current convection lines and thickened in other regions. The dissolution of the oxide layer along the current convection lines creates microor nano-pores on the titanium surface. ${ }^{54,57}$ Anodization produces modifications in the microstructure and the crystallinity of the titanium oxide layer. ${ }^{58}$ The anodization process is rather complex and depends on various parameters such as current density, 
concentration of acids, composition and electrolyte temperature. Anodized surfaces result in a strong reinforcement of the bone response with higher values for biomechanical and histomorphometric tests in comparison to machined surfaces..$^{59,60} \mathrm{~A}$ higher clinical success rate was observed for the anodized titanium implants in comparison with turned titanium surfaces of similar shapes. ${ }^{61}$ Two mechanisms have been proposed to explain this osseointegration: mechanical interlocking through bone growth in pores, and biochemical bonding. ${ }^{55,62}$ Modifications to the chemical composition of the titanium oxide layer have been tested with the incorporationof magnesium, calcium, sulfur or phosphorus. ${ }^{63,64}$ It has been found that incorporating magnesium into the titanium oxide layer leads to a higher removal torque value compared to other ions. ${ }^{55}$ In summary, surface roughness plays a major role in both the quality and rate of osseointegration of titanium dentalnHighly roughened implants such as TPS or gritblasted have been shown to favor mechanical anchorage and primary fixation to bone. Topographies in the nanometer range have been used to promote protein adsorption, osteoblastic cell adhesion and the rate of bone tissue healing in the periimplant region.

\section{Osteoconductive calcium phosphate coatings on dental implants}

Metal implants have been coated with layers of calcium phosphates mainly composed of hydroxyapatite. Following implantation, the release of calcium phosphate into the periimplant region increases the saturation of body fluids and precipitates a biological apatite onto the surface of the implant. ${ }^{65,66}$ This layer of biological apatite might contain endogenous proteins and serve as amatrix for osteogenic cell attachment and growth. ${ }^{67}$ The bone healing process around the implant is therefore enhanced by this biological apatite layer. The biological fixation of titanium implants to bone tissue is faster with a calcium phosphate coating than without. ${ }^{68,69}$ It iswellrecognized that calcium phosphate coatings have led to better clinical success rates in the long-term than uncoated titanium implants. ${ }^{68,70}$ These long-term success rates are due to a superior initial rate of osseointegration. ${ }^{70}$ Different methods have been developed to coat metal implants: plasmaspraying, sputter-deposition, sol-gel coating, electrophoretic deposition or biomimetic precipitation. However, only the plasma-spraying coating method has been used for titanium dental implants in clinical practice. Plasmaspraying is a technique in which hydroxyapatite (HA) ceramic particles are injected into a plasma torch at high temperature and projected on to the surface of the titanium where they condense and fuse together, forming a film. Plasma-sprayed coatings can be deposited with a thickness ranging from a few micrometers to a few millimeters. In order to obtain mechanical retention of the coating, the surface of the metallic implantmust be roughened, e.g. by means of gritblasting, when using this method. The plasmaspraying method has disadvantages, however, such as the porosity of the coating and residual stress at the substrate/coating interface, as well as drastic changes in the composition and crystallinity of the initial calcium phosphate powder. ${ }^{71,72}$ Several calcium phosphate phases have been observed in plasma-sprayed HA coatings such as tricalcium phosphates (_- and _-TCP), tetracalcium phosphate, calcium oxide and amorphous calcium phosphate (ACP). ${ }^{73,75}$ Plasma-sprayed HA coatings are usually composed of large crystalline HA particles embedded into a highly soluble amorphous calcium phosphate phase. Moreover, the plasmaspraying technique is not very effective for coating tiny dental implants with a complex shape. Plasma-sprayed HA-coated dental implants have also been associated with clinical problems. ${ }^{6,76,79}$ One of the major concerns with plasma-sprayed coatings is the possible delamination of the coating fromthe surface of the titanium implant and failure at the implant-coating interface despite the fact that the coating is wellattached to the bone tissue. The discrepancy in dissolution between the various phases that make up the coating has led to delamination, particle release and thus the clinical failure of implants. ${ }^{76,79}$ Coating delamination has been reported in dental situations where the efficacy of plasma-spraying is not optimal due to the size of the dental implants. ${ }^{6}$ Loosening of the coating has also been reported, especially when the implants have been inserted into dense bone. For all of the above reasons, the clinical use of plasmasprayed HA-coated dental implants is limited. Plasma-sprayed HA-coated prostheses are nevertheless highly successful in orthopedics. Despite their negative reputation in dental practice, a meta-analytic review did not show that long-term survival rates were inferior for plasma-sprayed HA-coated dental implants compared to other types of dental implant. ${ }^{78}$ 


\section{Future trends in dental implant surfaces}

A fewstrategies should be considered in order to improve both the short and long-term osseointegration of titanium dental implants. These future trends concern the modifications of surface roughness at the nanoscale level for promoting protein adsorption and cell adhesion, biomimetic calcium phosphate coatings for enhancing osteoconduction and the incorporation of biological drugs for accelerating the bone healing process in the peri-implant area.

\subsection{Surface roughness at the nanoscale level}

The chemistry and roughness of implant surfaces play amajor role in the biological events that follow implantation. Nevertheless, surfaces are often developed using an empirical approach with in vitro and in vivo tests. Most of the surfaces currently available have random topography with a wide range of thicknesses, from nanometers to millimeters. The exact biological role of these features is unknown because of the absence of standardized surfaces with repetitive topography at the nano-sized level (e.g. pits with fixed diameters and depth, lanes with controlled profiles). Such controlled or standardized surfaces might help to understand the interactions between specific proteins and cells. These standardized surfaces might also promote early bone apposition on the implants. Only a few studies have reported modifications to the roughness as well as the chemistry at the nanometer scale in a reproducible manner. Most of these attempts have used processing methods from the electronic industry such as lithography and surface laser-pitting. In vitro experimental studies ${ }^{80,82}$ have demonstrated that the attachment of osteoblastic cells was enhanced on submicron scale structures but not on smooth surfaces. Well-developed filopodia directly entered nanometersized pores for the initial attachment of the osteoblastic cells. These nanometer structures may also give the cells positive guidance by means of the selective attachment of osteoblasts to the implant surface. This selective attachment process might result in the improvement of initial healing around dental implants.

\subsection{Biomimetic calcium phosphate coatings on titanium dental implants}

In order to avoid the drawbacks of plasma-sprayed HA coatings, scientists have developed a new coating method inspired by the natural process of biomineralization. In this biomimetic method, the precipitation of calcium phosphate apatite crystals onto the titanium surface from simulated body fluids (SBF) formed a coating at room temperature. In order to accelerate the deposition of coatings from aqueous solutions, several methods have been developed. The first method involves the electrodeposition of calcium phosphate by using a current, a titanium cathode and a platinum anode. ${ }^{83,84}$ This electrochemical method is usually conducted in acidic calcium phosphate solutions and leads to the formation of brushite coatings which are subsequently converted into apatite by hydrothermal processing. The electrochemical deposition performed in simulated body fluid buffered at neutral pH can produce a carbonated apatite coating directly on the titanium surfaces.$^{85}$ This method makes possible perfect control of the thickness of the deposit on all. kinds of complicated surfaces. The time required for coating is very short and the process presents high reproducibility and efficacy..$^{86,87}$ The second method is based on the biomimetic precipitation of calcium phosphate on titanium surfaces by immersion in SBF. This method involves the heterogeneous nucleation and growth of bone-like crystals on the surface of the implant at physiological temperatures and under $\mathrm{pH}$ conditions. In general, two subsequent steps have been used to enhance the heterogeneous nucleation of the Ca-P. First, the implants are treated with an alkaline in order to form titanium hydroxyl groups on the titanium surface, to serve as nucleating points. ${ }^{88}$ Others have used high concentrations of calcium and phosphate in an increasing $\mathrm{pH}$ solution to form a thin layer on the titanium surface. In the second step, the coating develops under crystal growth conditions. ${ }^{89}$ The heterogeneous nucleation and growth of the $\mathrm{Ca}-\mathrm{P}$ on the titanium surface is initiated by the chemical bonding of nano-sized clusters, forming an interfacial unstructured matrix, stabilized by the presence of magnesium ions. ${ }^{90}$ The mechanical stability of the $\mathrm{Ca}-\mathrm{P}$ coating requires a rough titanium surface to ensure the mechanical stability of the coating. In addition, this physiological method broadens the variety of calcium phosphate phases that can be deposited, such as octacalcium phosphate or bone-like carbonate apatite. ${ }^{88,89}$ It has been shown that such biomimetic coatings aremore soluble in physiological fluids and resorbable by osteoclastic cells like dentin materials than high temperature coatings such as plasma-sprayed HA. ${ }^{91,92}$ The osseointegration of titanium implants coated with biomimetic calcium phosphate has been investigated in pre-clinical comparative models. 
These studies have demonstrated a higher bone-toimplant contact for biomimetic calcium phosphate coatings than for uncoated titanium implants. ${ }^{69,93}$ However, the osseointegration of titanium dental implants coated biomimetically has not yet been compared with other surface treatments in pre-clinical models.

\subsection{Incorporation of biologically active drugs into titanium dental implants}

The surface of titanium dental implants may be coated with bone-stimulating agents such as growth factors in order to enhance the bone healing process locally. Members of the transforming growth factor (TGF- $\beta$ ) superfamily, and in particular bone morphogenetic proteins (BMPs), TGF- $\beta 1$, plateletderived growth factor (PDGF) and insulin-like growth factors (IGF-1 and 2) are some of the most promising candidates for this purpose. Experimental data, in which BMPs have been incorporated into dental implants, have been obtained from a variety of methodologies..$^{94,99}$ The limiting factor is that the active product has to be released progressively and not in a single burst. Another possibility may be the adjunction of a plasmid containing the gene coding for a BMP. ${ }^{100}$ This possibility is limited due to the poor efficacy of inserting plasmids into the cells and the expression of the protein. In addition, overproduction of BMPs by cells might not be desirable after the bone healing process. The surface of implants could also be loaded withmolecules controlling the bone remodeling process. Incorporation of bone antiresorptive drugs, such as biphosphonates, might be very relevant in clinical cases lacking bone support, e.g. resorbed alveolar ridges. It has been shown recently that a biphosphonate incorporated on to titanium implants increased bone density locally in the peri-implant region. ${ }^{101}$ The effect of the antiresorptive drug seems to be limited to the vicinity of the implant. Experimental in vivo studies have demonstrated the absence of negative effects but only a slight increase in dental implant osseointegration. ${ }^{101,102}$ Other experimental studies using plasma-sprayed HA-coated dental implants immersed in pamidronate or zoledronate demonstrated a significant increase in bone contact area. ${ }^{104,106}$ The main problem lies in the grafting and sustained release of antiresorptive drugs on the titanium implant surface. Due to the high chemical affinity of bisphosphonates for calcium phosphate surfaces, incorporation of the antiresorptive drug on to dental implants could be achieved by using the biomimetic coating method at room temperatures. However, the ideal dose of antiresorptive drug will have to be determined because the increase in peri-implant bone density is biphosphonate concentrationdependent. ${ }^{106}$

\section{Conclusion}

There are a number of surfaces commercially available for dental implants. Most of these surfaces have proven clinical efficacy (>95\% over 5 years). However, the development of these surfaces has been empirical, requiring numerous in vitro and in vivo tests. Most of these tests were not standardized, using different surfaces, cell populations or animal models. The exact role of surface chemistry and topography on the early events of the osseointegration of dental implants remain poorly understood. Furthermore, comparative clinical studies with different implant surfaces are rarely performed. The future of dental implantology should aim at developing surfaces with controlled and standardized topography or chemistry. This approach is the only way to understand protein, cell and tissue interactions with implant surfaces. The local release of bone-stimulating or resorptive drugs in the periimplant region may also respond to difficult clinical situations with poor bone quality and quantity. These therapeutic strategies should ultimately enhance the osseointegration process of dental implants for their immediate loading and long-term success.

\section{REFERENCES}

1. Albrektsson T, Branemark PI, Hansson HA, Lindstrom J. Osseointegrated titanium implants. Requirements for ensuring a long-lasting, direct bone-to-implant anchorage in man.Acta Orthop Scand 1981;52(2):155-170.

2. Steinemann S. Titanium-the material of choice? Periodontology 2000 1998;17:7-21.

3. Buser D, Broggini N, Wieland M, Schenk RK, Denzer AJ, Cochran DL, et al. Enhanced bone apposition to a chemically modified SLA titanium surface. J Dent Res 2004;83:529-533.

4. Zhao G, Schwartz Z, Wieland M, Rupp F, Geis-Gerstorfer J, Cochran $D L$, et al. High surface energy enhances cell response to titanium substrate microstructure. J Biomed Mater Res A 2005;74:49-58.

5. Bagno A, Di Bello C. Surface treatments and roughness properties of Ti-based biomaterials. J Mater Sci Mater Med 2004;15:935-949.

6. Giavaresi G, Fini M, Cigada A, Chiesa R, Rondelli G, Rimondini L, et al Mechanical and histomorphometric evaluations of titanium implants with different surface treatments inserted in sheep cortical bone. Biomaterials 2003;24:1583-594.

7. Carlsson L, Albrektsson T, Berman C. Bone response to plasmacleaned titanium implants. Int J Oral Maxillofac Implants 1989;4:199-204. 
8. Wennerberg A, Bolind P, Albrektsson T. Glow discharge pre-treated implants combined with temporary bone ischaemia. Swed Dent J 1991;15:95-101.

9. Cochran DL, Schenk RK, Lussi A, Higginbottom FL, Buser D. Bone response to unloaded and loaded titanium implants with a sandblasted and acid-etched surface: a histometric study in the canine mandible. J Biomed Mater Res 1998;40:1-11.

10. Wennerberg A, Hallgren C, Johansson C, Danelli S. A histomorphometric evaluation of screw-shaped implants each prepared with two surface roughnesses. Clin Oral Implants Res 1998;9:11-19.

11. Buser D, Schenk R, Steinemann S, Fiorellini J, Fox C, Stich H. Influence of surface characteristics on bone integration of titanium implants. A histomorphometric study in miniature pigs. J Biomed Mater Res 1991;25:889-902

12. Gotfredsen K, Wennerberg A, Johansson C, Skovgaard LT, Hjorting Hansen E. Anchorage of TiO2-blasted, HA-coated, and machined implants: an experimental study with rabbits. J Biomed Mater Res 1995;29:1223-1231.

13. Wennerberg A, Albrektsson T, Albrektsson B, Krol JJ. Histomorphometric and removal torque study of screw-shaped titanium implants with three different surface topographies. Clin Oral Implant Res 1996;6:24-30.

14. Becker W, Becker BE, Ricci A, Bahat O, Rosenberg E, Rose LF, et al. A prospective multicenter clinical trial comparing one- and two-stage titanium screw-shaped fixtures with one-stage plasma-sprayed solid-screw fixtures. Clinlmplant Dent Relat Res 2000;2:159-165.

15. Albrektsson T, Wennerberg A. The impact of oral implants-past and future, 1966-2042. J Can Dent Assoc 2005;71:327.

16. Hansson $\mathrm{S}$, Norton M. The relation between surface roughness and interfacial shear strength for bone-anchored implants. A mathematical model. J Biomech 1999;32:829-836.

17. TestoriT,Wiseman L,Woolfe S,Porter S.A prospective multicenter clinical study of the Osseotite implant: four-year interim report. Int J Oral Maxillofac Implants 2001;16:193-200.

18. Conner K, Sabatini R, Mealey B,Takacks V, Mills M, Cochran D. Guided bone regeneration around titanium plasma-sprayed, acid-etched and hydroxyapatite-coated implants in the canine model. J Periodontol 2003;74:658-668.

19. Esposito M, Coulthard P, Thomsen P, Worthington HV. Interventions for replacing missing teeth: different types of dental implants. Cochrane Database Syst Rev 2005;25:CD003815.

20. Brett PM, Harle J, Salih V, Mihoc R, Olsen I, Jones FH, et al. Roughness response genes in osteoblasts. Bone 2004;35:124-133.

21. Urban RM, Jacobs JJ, Tomlinson MJ, Gavrilovic J, Black J, Peoch M. Dissemination of wear particles to the liver, spleen and abdominal lymph nodes of patients with hip or knee replacement. J Bone Jt Surg Am 2000;82:457-477.

22. Browne $M$, Gregson PJ. Effect of mechanical surface pretreatment on metal ions release. Biomaterials 2000;21:385-392.

23. Martini D, Fini M, De Pasquale V, Bacchelli B, Gamberini M, Tiniti A, et al. Detachment of titanium and fluorohydroxyapatite particles in unloaded endosseous implants. Biomaterials 2003;24:1309-1316.

24. Roccuzzo M, Bunino M, Prioglio F, Bianchi SD. Early loading of sandblasted and acid-etched (SLA) implants: a prospective splitmouth comparative study. Clin Oral Implants Res 2001;12:572-578.

25. Taba Junior M, Novaes Junior AB, Souza SL, Grisi MF, Palioto DB, Pardini LC.Radiographic evaluation of dental implants with different surface treatments: an experimental study in dogs. Implant Dent 2003;12:252-258.

26. Ong JL, Carnes DL, Bessho K. Evaluation of titanium plasma-sprayed and plasma-sprayed hydroxyapatite implants in vivo. Biomaterials 2004;25:4601-4606. [27] Aparicio C, Gil FJ, Fonseca C, Barbosa M, Planell JA.

Corrosion behavior of commercially pure titanium shotblasted with different materials and size of shot particlesfor dental implant applications. Biomaterials 2003;24:263-273.

27. Ivanoff CJ, Hallgren C, Widmark G, Sennerby L, Wennerberg A Histologic evaluation of the bone integration of $\mathrm{TiO}(2)$ blasted and turned titanium microimplants in humans. Clin Oral Implants Res 2001;12:128-134.

28. Ivanoff CJ, Hallgren C, Widmark G, Sennerby L, Wennerberg A Histologic evaluation of the bone integration of $\mathrm{TiO}(2)$ blasted and turned titanium microimplants in humans. Clin Oral Implants Res 2001;12:128-134.

29. Rasmusson L, Kahnberg KE, Tan A. Effects of implant design and surface on bone regeneration and implant stability:an experimental study in the dog mandible. Clin Implant Dent Relat Res 2001;3:2-8.

30. Gotfredsen K, Karlsson U. A prospective 5-year study of fixed partial prostheses supported by implants with machined and TiO2-blasted surface. J Prosthodont2001;10:2-7.

31. Rasmusson L, Roos J, Bystedt H. A 10-year follow-up study of titanium dioxide-blasted implants. Clin Implant Dent Relat Res 2005;7:36-42.

32. van Steenberghe D, De Mars G, Quirynen M, Jacobs R, Naert I. A prospective split-mouth comparative study of two screw-shaped self-tapping pure titanium implant systems. Clin Oral Implants Res 2000;11:202-209.

33. Astrand $P$, Engquist $B$, Dahlgren $S$, Engquist E, Feldmann $H$, Grondahl K. Astra Tech and Branemark System implants: a prospective 5-year comparative study. Results after one year. Clin Implant Dent Relat Res 1999;1:17-26.

34. Abron A, Hopfensperger M, Thompson J, Cooper L. Evaluation of a predictive model for implant surface topography effects on early osseointegration in the rat tibiamodel. J Prosth Dent 2001;85:4046.

35. Novaes A, Souza S, de Oliveira P, Souza A.

Histomorphometric analysis of the bone-implant contact obtained with 4 different implant surface treatments placed side by side in the dog mandible. Int J Oral Maxillofac Implants 2002;17:377-383.

36. Piatelli M, Scarano A, Paolantonio M, lezzi G, Petrone G, Piatelli A Bone response to machined and resorbable blast material titanium implants: an experimental study inrabbits. J Oral Implantol 2002;28:2-8.

37. Mueller WD, Gross U, Fritz T, Voigt C, Fischer P, Berger G, et al Evaluation of the interface between bone and titanium surfaces being blasted by aluminium oxide or bioceramic particles. Clin Oral Implants Res 2003;3:349-356.

38. Massaro C, Rotolo F, De Riccardis F, Milella E, Napoli A, Wieland M, et al.Comparative investigation of the surface of commercial titanium dental implants.Part 1:chemicalcomposition.J Mater Sci Mater Med 2002; 13:535-348.

39. Zinger $\mathrm{O}$, Anselme K, Denzer A, Habersetzer P, Wieland M, Jeanfils J, et al. Time-dependent morphology and adhesion of osteoblastic cells on titanium model surfaces featuring scale-resolved topography. Biomaterials 2004;25:2695-2711. 
40. Wong M, Eulenberger J, Schenk R, Hunziker E. Effect of surface topology on the osseointegration of implant materials in trabecular bone. J Biomed Mater Res 1995;29:1567-1575.

41. Cho SA, Park KT. The removal torque of titanium screw inserted in rabbit tibia treated by dual acid etching. Biomaterials 2003;24:36113617.

42. Park JY, Davies JE. Red blood cell and platelet interactionsn with titanium implant surfaces. Clin Oral Implants Res 2000;11:530-539.

43. Trisi P, Lazzara R, Rebaudi A, Rao W, Testori T, Porter SS. Bone-implant contact on machined and dual acid-etched surfaces after 2 months of healing in the human maxilla. J Periodontol 2003;74:945-956.

44. Davies JE. Mechanisms of endosseous integration. Int J Prosthodont 1998;11:391-401.

45. Trisi P, Lazzara R, Rao W, Rebaudi A. Bone-implant contact and bone quality: evaluation of expected and actual bone contact on machined and osseotite implant surfaces. Int J Periodontics Restorative Dent 2002;22:535-545.

46. Trisi P, Marcato C, Todisco M. Bone-to-implant apposition with machined and MTX microtextured implant surfaces in human sinus grafts. Int J Periodontics Restorative Dent2003;23:427-437.

47. Cochran DL, Buser D, ten Bruggenkate CM, Weingart D, Taylor TM, Bernard JP, et al. The use of reduced healing times on ITI implants with a sandblasted and acid-etched (SLA) surface: early results from clinical trials on ITI SLA implants. Clin Oral Implants Res 2002;13:144153.

48. Novaes Jr AB, Papalexiou V, Grisi MF, Souza SS, Taba Jr M, Kajiwara JK. Influence of implant microstructure on the osseointegration of immediate implants placed in periodontally infected sites. A histomorphometric study in dogs. Clin Oral Implants Res 2004;15:34-43.

49. Papalexiou V, Novaes Jr AB, Grisi MF, Souza SS, Taba Jr M, Kajiwara $J K$. Influence of implant microstructure on the dynamics of bone healing around immediate implants placed into periodontally infected sites. A confocal laser scanning microscopic study. Clin Oral Implants Res2004;15:44-53

50. Ellingsen JE. Pre-treatment of titanium implants with fluoride improves their retention in bone. J Mater Sci Mater Med 1995;6:749758.

51. Ellingsen JE, Johansson CB, Wennerberg A, Holmen A. Improved retention and bone-to-implant contact with fluoride-modified titanium implants. Int J Oral Maxillofac Implants 2004;19:659-666.

52. Cooper LF, Takabe J, Guo J, Abron A, Holmen A, Ellingsen JE. Fluoride modification effects on osteoblast behavior and bone formation at $\mathrm{TiO}(2)$ grit-blasted c.p. titanium endosseous implants. Biomaterials 2006;27:926-936.

53. Yokoyama K, Ichikawa T,Murakami H,Miyamoto Y, Asaoka K. Fracture mechanisms of retrieved titanium screw thread in dental implants. Biomaterials 2002;23:2459-2465.

54. Sul YT, Johansson CB, Jeong Y, Roser K, Wennerberg A, Albrektsson T. Oxidized implants and their influence on the bone response. J Mater Sci Mater Med 2001;12:1025-1031.

55. Sul YT, Johansson C, Wennerberg A, Cho LR, Chang BS, Albrektsson T. Optimum surface properties of oxidized implants for reinforcement of osseointegration: surface chemistry, oxide thickness, porosity, roughness, and crystal structure. Int J Oral Maxillofac Implants 2005;20:349-359.

56. Xiropaidis AV, Qahash M, Lim WH, Shanaman RH, Rohrer MD, Wikesjo UM, et al. Bone-implant contact at calcium phosphate-coated and porous titanium oxide (TiUnite)-modified oral implants. Clin Oral Implants Res 2005;16:532-539.

57. Huang YH, Xiropaidis AV, Sorensen RG, Albandar JM, Hall J, Wikesjo UM. Bone formation at titanium porous oxide (TiUnite) oral implants in type IV bone. Clin Oral Implants Res 2005;16:105-111.

58. Sul YT, Johansson CB, Roser K, Albrektsson T. Qualitative and quantitative observations of bone tissue reactions to anodised implants. Biomaterials 2002;23:1809-1817.

59. Sul YT, Johansson CB, Jeong $Y$, Wennerberg A, Albrektsson $T$. Resonance frequency and removal torque analysis of implants with turned and anodized surface oxides. Clin Oral Implants Res 2002;13:252-259.

60. Rocci A, Martignoni M, Gottlow J. Immediate loading of Branemark System TiUnite and machined-surface implants in the posterior mandible: a randomized open-ended clinical trial.Clin Implant Dent Relat Res 2003;5:S57-63.

61. Jungner $\mathrm{M}$, Lundqvist $\mathrm{P}$, Lundgren $\mathrm{S}$. Oxidized titanium implants (Nobel Biocare TiUnite) compared with turned titanium implants (Nobel Biocare mark III) with respect to implant failure in a group of consecutive patients treated with early functional loading and two-stage protocol. Clin Oral Implants Res 2005;16:308-312.

62. Schupbach P, Glauser R, Rocci A, Martignoni M, Sennerby L, Lundgren $A$, et al.The human bone-oxidized titanium implant interface: a light microscopic, scanning electron microscopic, back-scatter scanning electron microscopic, and energy-dispersive X-ray study of clinically retrieved dental implants. Clin Implant Dent Relat Res 2005;7:S3643.

63. SulYT, Johansson CB, Albrektsson T.Oxidized titanium screws coated with calcium ions and their performance in rabbit bone. Int J Oral Maxillofac Implants 2002;17:625-634.

64. Sul YT, Byon ES, Jeong Y. Biomechanical measurements of calciumincorporated oxidized implants in rabbit bone: effect of calcium surface chemistry of a novel implant. Clin Implant Dent Relat Res 2004;6:101-110.

65. De Groot K, Wolke JG, Jansen JA. Calcium phosphate coatings for medical implants. Proc Inst Mech Eng 1998;212:137-147.

66. Daculsi G, Laboux O, Malard O, Weiss P. Current state of the art of biphasic calcium phosphate bioceramics. J Mater Sci Mater Med 2003;14:195-200.

67. Davies JE. Understanding peri-implant endosseous healing. J Dent Educ 2003;67:932-949.

68. Morris HF, Ochi S, Spray JR, Olson JW. Periodontal-type measurements associated with hydroxyapatite-coated and non-HAcoated implants: uncovering to 36 months. Ann Periodontol 2000;5:56-67.

69. Barrere F, van der Valk CM, Meijer G, Dalmeijer RA, de GrootK, Layrolle P. Osteointegration of biomimetic apatite coating applied onto dense and porous metal implants in femurs of goats.J Biomed Mater Res 2003;67:655-665.

70. Geurs NC, Jeffcoat RL, McGlumphy EA, Reddy MS, Jeffcoat MK Influence of implant geometry and surface characteristics on progressive osseointegration. Int J Oral Maxillofac Implants 2002;17:811-815.

71. Filiaggi MJ, Coombs NA, Pilliar RM. Characterization of the interface in the plasma-sprayed HA coating/Ti-Al6-4V implant system. J Biomed Mater Res 1991;25:1211-1230.

72. Radin S, Ducheyne P. Plasma spraying induced changes of calcium phosphate ceramic characteristics and the effect on in vitro stability. Mater Med 1992;3:33-42. 
73. De Groot K, Wolke JCG, Jansen JA. State of the art: hydroxylapatite coatings for dental implants. J Oral Implant 1994;20:232-234.

74. Kim Y, LeGeros J, LeGeros RZ. Characterization of commercial HAcoated implants. J Dent Res 1994;73:137 [abstract no. 287].

75. LeGeros RZ, LeGeros JP, Kim Y, Kijkowska R, Zheng R, Bautista C, et al. Calcium phosphates in plasma-sprayed HA coatings. Ceram Trans 1995;48:173-189.

76. Wheeler S. Eight-year clinical retrospective study of titanium plasma-sprayed and hydroxyapatite-coated cylinder implants. Int J Oral Maxillofac Implants 1996;11:340-350.

77. Chang YL, Lew D, Park JB, Keller JC. Biomechanical and morphometric analysis of hydroxyapatite-coated implants with varying cristallinity. J Oral Maxillofac Surg 1999;57:1096-1108.

78. Lee J, Rouhfar L, Beirne O. Survival of hydroxypatite-coated implan[78] Lee J, Rouhfar L, Beirne O. Survival of hydroxypatitecoated implants: a meta-analytic review. J Oral Maxillofac Surg 2000;58:1372-1379 [discussion 1379-1380].

79. Tinsley D, Watson C, Russell J.A comparison of hydroxyapatite coated implant retained fixed and removable mandibular prostheses over 4 to 6 years. Clin Oral Implant Res 2001;12:159-166.

80. Anselme K, Bigerelle M, Noel B, lost A, Hardouin P. Effect of grooved titanium substratum on human osteoblastic cell growth.J Biomed Mater Res 2002;60:529-540.

81. Bigerelle M, Anselme K, Noel B, Ruderman I, Hardouin P, lost A Improvement in the morphology of Ti-based surfaces: a new process to increase in vitro human osteoblast response. Biomaterials 2002;23:1563-1577.

82. Zhu X, Chen J, Scheideler L, Altebaeumer T, Geis-Gerstorfer J, Kern D. Cellular reactions of osteoblasts to micron- and submicron-scale porous structures of titanium surfaces. Cells Tissues Organs 2004;178:13-22.

83. Wang X, Yan W, Hayakawa S, Tsuru K, Osaka A. Apatite deposition on thermally and anodically oxidized titanium surfaces in a simulated body fluid. Biomaterials 2003;24:4631-4637.

84. Yang B, Uchida M, Kim HM, Zhang X, Kokubo T. Preparation of bioactive titanium metal via anodic oxidation treatment. Biomaterials 2004;25:1003-1010.

85. Wang J, de Boer J, de Groot K. Preparation and characterization of electrodeposited calcium phosphate/chitosan coating on Ti6Al4V plates. J Dent Res 2004;83:296-301.

86. Ban S, Maruno S. Deposition of calcium phosphate on titanium by electrochemical process in simulated body fluid. Jpn J Appl Phys 1993;32:1577-80ts: a meta-analytic review. J Oral Maxillofac Surg.

87. Sena LA, Andrade MC, Rossi AM, Soares GA. Hydroxyapatite deposition by electrophoresis on titanium sheets with different surface finishing. J Biomed Mater Res 2002;60:1-7.

88. KokuboT,Kushitani $\mathrm{H}, \mathrm{Abe}, \mathrm{Y}, Y a m a m u r o T$. Apatite coating on various substrates in simulated body fluids. Bioceramics 1989;2:235-242.

89. Habibovic P, Barr'ere F, van Blitterswijk CA, de Groot K, Layrolle P. Biomimetic hydroxyapatite coating on metal implants.J Am Ceram Soc 2002; 85:517-522.

90. Barrere F, Snel M, Van Blitterswijk C, de Groot K, Layrolle P. Nanoscale study of the nucleation and growth of calciumphosphate coating on titanium implants. Biomaterials2004;25:2901-2910.

91. Barrere F, van der Valk CM,Dalmeijer RA, van Blitterswijk CA, de Groot $\mathrm{K}$, Layrolle $\mathrm{P}$. In vitro and in vivo degradation of biomimetic octacalcium phosphate and carbonate apatite coatings on titanium implants. J Biomed Mater Res 2003;64:378-387.
92. Leeuwenburgh S, Layrolle P, Barr`ere F, de Bruijn J, Schoonman J, van Blitterswijk CA, et al. Osteoclastic resorption of biomimetic calcium phosphate coatings in vitro. J Biomed Mater Res 2001;56:208-215.

93. Habibovic P, Li J, van der Valk CM, Meijer G, Layrolle P, van Blitterswijk $C A$, et al. Biological performance of uncoated and octacalcium phosphate-coated Ti6Al4V. Biomaterials 2005;26:23-36.

94. Bessho K, Carnes DL, Cavin R, Chen HY, Ong JL. BMP stimulation of bone response adjacent to titanium implants in vivo. Clin Oral Implants Res 1999;10: 212-218.

95. Wikesjo UM, Sorensen RG, Kinoshita A, Wozney JM. RhBMP-2/ alphaBSM induces significant vertical alveolar ridge augmentation and dental implant osseointegration. Clin Implant Dent Relat Res 2002;4:174-182

96. Tatakis DN, Koh A, Jin L, Wozney JM, Rohrer MD, Wikesjo UM. Periimplant bone regeneration using recombinant human bone morphogenetic protein- 2 in a canine model: a dose-response study. J Periodontal Res 2002;37:93-100.

97. Stenport VF, Roos-Jansaker AM, Renvert S, Kuboki Y, Irwin C, Albrektsson T, et al. Failure to induce supracrestal bone growth between and around partially inserted titanium implants using bone morphogenetic protein (BMP): an experimental study in dogs. Clin Oral Implants Res 2003;14:219-225.

98. Boyne P, Jones SD. Demonstration of the osseoinductive effect of bone morphogenetic protein within endosseous dental implants. Implant Dent 2004;13:180-184.

99. Liu Y, de Groot K, Hunziker EB. BMP-2 liberated from biomimetic implant coatings induces and sustains direct ossification in an ectopic rat model. Bone 2005;36:745-757.

100. Huang YC, Simmons C, Kaigler D, Rice KG, Mooney DJ. Bone regeneration in a rat cranial defect with delivery of $\mathrm{PEl}$-condensed plasmid DNA encoding for bone morphogenetic protein-4 (BMP4). Gene Ther 2005;12:418-426.

101. Josse S, Faucheux C, Soueidan A, Grimandi G, Massiot D, A1 onso B et al. Chemically modified calcium phosphates as novel materials for bisphosphonate delivery. Adv Mater 2004;16:1423-1427.

102. Meraw SJ, Reeve CM. Qualitative analysis of peripheral peri-implant bone and influence of alendronate sodium on early bone regeneration. J Periodontol 1999;70:1228-1233.

103. Meraw SJ, Reeve CM, Wollan PC. Use of alendronate in peri-implant defect regeneration. J Periodontol 1999;70:151-158.

104. Yoshinari M, Oda Y, Ueki H, Yokose S. Immobilization of bisphosphonates on surface modified titanium. Biomaterials 2001;22:709-715.

105. Kajiwara H, Yamaza T, Yoshinari M, Goto T, lyama S, Atsuta I, et al. The bisphosphonate pamidronate on the surface of titanium stimulates bone formation around tibial implantsin rats. Biomaterials 2005;26:581-587.

106. Peter B, Pioletti DP, Laib S, Bujoli B, Pilet P, Janvier P, et al. Calcium phosphate drug delivery system: influence of local zoledronate release on bone implant osteointegration. Bone 2005;36:52-60.

107. Mabboux F, Ponsonnet L, Morrier JJ, Jaffrezic N, Barsotti O. Surface free energy and bacterial retention to saliva-coateddental implant materials-an in vitro study. Colloids Surf B Biointerfaces 2004;39:199205.

108. Ferraz MP, Monteiro FJ, Serro AP, Saramago B, Gibson IR, Santos JD. Effect of chemical composition on hydrophobicity and zeta potential of plasma sprayed $\mathrm{HA} / \mathrm{CaO}-\mathrm{P} 2 \mathrm{O} 5$ glass coatings. Biomaterials 2001;22:3105-112. 